\title{
Sociobiology
}

RESEARCH ARTICLE - ANTS

\section{Temporal Turnover of Species Maintains Ant Diversity but Transforms Species Assemblage Recovering from Fire Disturbance}

\author{
DV ANJOS ${ }^{1}$, RBF CAMPOS ${ }^{1,2}$, SP RIBEIRO ${ }^{1}$ \\ 1 - Universidade Federal de Ouro Preto, Ouro Preto, MG, Brazil \\ 2 - Universidade do Vale do Rio Doce, Governador Valadares, MG, Brazil
}

\author{
Article History \\ Edited by \\ Gilberto M. M. Santos, UEFS, Brazil \\ Received: $\quad 01$ December 2014 \\ Initial acceptance: 31 March 2015 \\ Final acceptance: 01 May 2015

\section{Keywords} \\ Natural succession, burn, rupestrian complex, \\ species substitution.

\section{Corresponding author} \\ Renata Bernardes Faria Campos \\ Sala 01 - PVA - Campus II UNIVALE \\ Av. Israel Pinheiro 2000, Bairro Universitário, \\ Governador Valadares-MG, Brazil \\ E-Mail: rbfcampos@gmail.com
}

\begin{abstract}
The rupestrian complex is a montane transitional vegetation type between the Brazilian Savanna ('Cerrado') and the Atlantic Forest, frequently threatened by human activities. In this study, we evaluated the recovery to fire disturbance of ant fauna in an environment evolved under fire regime. We confirmed that the ant diversity recovers quickly after the fire. However, our results show that ant assemblage in burned areas presented greater foraging activity, here detected as higher abundance. The ant composition changed over time, being that species turnover lead to a strikingly different species composition comparing burned to unburned areas after 16 months of recovering. In fact, both areas changed their ant composition through species turnover, but we believe that the mechanisms that act in species turnover are different in each area. Along time, in burned areas the fauna maintained a constant species diversity but dramatically changed species assemblage due to appearance of several species not found in the unburned area.
\end{abstract}

\section{Introduction}

Fire is a common environmental disturbance in the Brazilian Cerrado (Kauffmann et al., 1994; Miranda et al., 2002). The very long time of exposure to fire, makes that many species are adapted to its effect and exhibit high resistance and resilience to it (Hoffmann et al., 2003).Therefore, the ecosystems have evolved relations with the occurrence of fire and much of its dynamics is related to natural fire cycles, ensuring its natural succession. Nevertheless, as in other worldwide savannas, the human presence has intensified the natural dynamics of fire.

Considering that the fire impact has become increasingly frequent it is important to understand the fire effects in these environments (Cochrane et al., 1999; Conceição \& Pirani, 2007). The "High Altitude Rupestrian Complex" is a definition proposed by Semir (1991) and Benites et al. (2003), based on the heterogeneity of montane habitats and their endemic species, presenting different types of rocky woody vegetation, from grasslands to low, dense forests (Alves et al., 2014). This ecosystem is in a transition between Brazilian Savanna ('Cerrado') and Atlantic rainforest being many plant species common to these two biomes (Harley, 1995; Viana \& Filgueiras, 2008), thus it is composed by species adapted and not adapted to fire. This ecosystem is frequently threatened by human activities (see Fernandes et al., 2014), and little is known about the effects of fire on communities associated with rupestrian complex vegetation, increasing the importance of the present study.

Fire may reduce the faunal diversity directly through mortality or evasion, and indirectly through habitat change and food shortage (Frizzo et al., 2011; Fagundes et al., 2015). However, the effects of fire can be specific and some taxa can benefit (Frizzo et al., 2011) while others perish (Andersen \& Muller, 2000; Vasconcelos et al., 2009). Ant diversity is directly affected by vegetation structure, mostly by the occurrence of plants producing extrafloral nectar, hosting honeydew-hemipterans and providing cavities for nesting (Farji-Brener et al., 2002; Parr et al., 2004; Ratchford et al., 2005; Fagundes et al., 2015). In environments with vegetation adapted for and more resilient to burning, one may expect a 
quick recovery of plants (Hoffmann et al., 2003; Simon et al., 2009) and consequently, a quick ant assemblage recovery (Parr et al., 2004; Ratchford et al., 2005). In fact, many studies did not detect decrease in ant diversity after fire (Parr et al., 2004; Andersen et al., 2006; Arnan et al., 2006), and the fire effects may disappear after two years of recovering (Vasconcelos et al., 2009). Thus, we can predict that the ant assemblage might quickly return to an unburned conduction, especially in ecosystem adapted to fire (Ratchford et al., 2005).

Ants may be important species in the beginning of the ecological succession after fire, because many species are generalists and tolerant to intense fluctuations of abiotic conditions (Andersen \& Muller, 2000; Campos et al., 2007; Costa et al., 2010). Thus, ants act as pioneers in the secondary succession by performing several ecological functions (Fowler et al., 1991) affected by the fire (Andersen \& Muller, 2000). In this context, we evaluated the ant fauna recover after a fire in an ecotonal zone between grassland and montane low forest, within a typical rupestrian complex vegetation. Since the studied sites present a long term history of disturbance by fire, we expect that this is a fire resistant ecosystem. We tested the hypothesis that the ant diversity recovers quickly after the fire, considering that the ant assemblage may show a faster recovery than the vegetation. We also tested the hypothesis that the succession dynamics of ant assemblage must be different between areas, so we expected a higher species turnover along time in burned than in the unburned areas, where we expect to find an ant species composition nestedness pattern.

\section{Material and Methods}

\section{Study area}

We performed the study in the Parque Estadual do

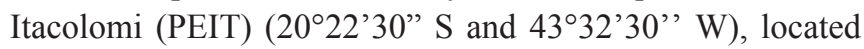
in Ouro Preto, Minas Gerais State, Brazil. The park was created in 1967 with an area of 7,543 ha, and the vegetation is composed of seasonal forests, gallery forests, forests of the candeia tree [Eremanthus erythropappus (DC.) MacLeish (Asteraceae)], Araucaria angustifolia forest remnants, and ferruginous and quartzite grasslands (Pedreira \& Souza, 2009). We conducted the survey in a rupestrian ecosystem which is a complex mosaic of old secondary forests and areas where early successional stages of a forest are kept as grasslands possibly due to a long term human impact, along with natural grasslands, also depauperate of species if compared with other rupestrian grasslands. Even if, PEIT is not highly diverse as typical rupestrian grasslands from other places as Serra do Cipó (Giulietti\& Pirani, 1988). Gastauer et al. (2012) evidences the park's classification as a local hotspot of biodiversity. The climate presents mild temperate with dry and warm summers; the average annual temperature ranges from 17.4 to $19.8^{\circ} \mathrm{C}$ and the average annual precipitation ranges from 1,100 to $1,800 \mathrm{~mm}$. The relief is mountainous, with altitudes ranging from $900-1,772 \mathrm{~m}$ a.s.l. (Itacolomi Peak summit). We surveyed an area of four hectare of burned rupestrian complex vegetation (hereafter "burned area") with a record of frequent fire in the last decade and compared it to the sampled ant fauna with a vicinal portion of this area, with unburned vegetation considered as our reference (hereafter "unburned area"). Both areas are situated above $1200 \mathrm{~m}$ a.s.l, have low declivity, similar soil structure and vegetation dominated by grass and herbs with many shrubs sparsely distributed.

In each area, we marked one $15 \mathrm{~m} \mathrm{x} 20 \mathrm{~m}$ grid. The grids were $300 \mathrm{~m}$ apart in order to reduce effects of environmental variations (Vasconcelos et al., 2008). Within each grid, we demarcated four lines with five pitfalls trap $5 \mathrm{~m}$ apart each other. The pitfall was a $20 \mathrm{~mL}$ plastic cup with $3 \mathrm{~cm}$ diameter and $10 \mathrm{~cm}$ deep filled with a solution of water, salt (5\%) and a few drops of detergent to break the water tension. The pitfalls stayed in the field for 96 hours. The first sample was four months after burning (October/2010), in the beginning of the rainy season. We did 12 samples monthly. The ants were identified according to Fernández et al. (2003) and by comparison with morphotypes of the Entomology Collection of the Departament of Environment, Evolution and Biodiversity of Federal University of Ouro Preto, Ouro Preto, Brazil. Voucher specimens were deposited in this collection.

\section{Data analysis}

We first plot curves of accumulated species richness to compare burned and unburned areas, to allow us to assess if our 16 months of species survey were sufficient to reach completeness (a plateau). Since pitfall traps measure active ants, we used species frequency of occurrences per sampling (pitfall trap), on the $\mathrm{X}$ axis.

For the subsequent analyses, we considered the monthly sum of workers (abundance) and ants species number (richness) collected in the 20 pitfalls of each area as repeated measures (12 samples per area). We tested the difference in ant abundance and ant richness (dependent variables) between burned and unburned areas (fixed factor: area, which corresponds to treatment) using analysis of variance (repeated measures ANOVA) considering the months as random blocks to prevent time effect.

Finally, we tested the temporal changes of the ant fauna composition through the 'Seriation' model. This model orders the species throughout a predetermined gradient (recovery time, in our case) using the algorithm proposed Brower \& Kile (1988). Then, the program runs a Monte Carlo simulation creating 30 random matrices from the original data with the same number of occurrences for each taxon. Thus, the model test if the observed gradient in the original data is different from a random one.

We also verify temporal changes of beta diversity as described by Baselga (2010) and Baselga et al. (2012) 
to find what mechanism (turnover or nestedness) determine the beta diversity at different scales, spatial and temporal. In this study, this analysis was used to understand what is the main mechanism influencing the beta diversity temporally in burned and unburned areas. So we expected a higher temporal turnover in burned areas and a temporal nestedness in the unburned areas. Seriation test was carried out using PAST v3.01 and all other analyses were carried out in R (R Development Core Team, 2006).

\section{Results}

We collected 1706 of ants belonging to 55 species. The burned area present 1203 (70.5\%) ants from 46 species, while the unburned area had $503(29.5 \%)$ ants from 39 species (Table 1). The mean abundance of ants (ants per month) was higher in the burned area compared to unburned area (ANOVA: $F_{1,11}=11.1 . p=0.007$ ) (Fig 1a). On the other hand, the mean species richness did not differ between areas $\left(\mathrm{F}_{1,11}=0.6, \mathrm{p}>0.5\right)(\mathrm{Fig} 1 \mathrm{~b})$. The mean abundance $\left(\mathrm{F}_{1,11}=9.2\right.$, $\mathrm{p}=0.0005)$ and mean richness $\left(\mathrm{F}_{1,11}=7.2, \mathrm{p}=0.002\right)$ of ants decreased over the time (Fig 1a, b). The curve of accumulated species richness indicate we have a plateau in both areas, and we have a separation from each other considering the last samples added only (Fig 2).

From the total of 56 sampled species, 31 (56\%) were common in both areas. The burned area presented $16(30 \%)$ exclusive species while unburned area presented 8 (14\%) (Table 1- Appendix). We observed a temporal turnover of species in the burned area is nonrandom (Seriation: Monte Carlo, $Z=2.46, p=0.01)$, differently from the unburned area $(Z=0.4, p=0.7)$ (Fig 3). Therefore, in the burned area there was a directional variation in species composition than in the unburned area, where the change in the composition did not differ from that expected by chance. Our results shows that in both areas temporal turnover contributed strongly to the beta diversity. Turnover explains $98.7 \%$ of beta diversity from burned area $(\beta \mathrm{SOR}=0.991: \beta \mathrm{SIM}=0.978, \beta \mathrm{NES}=0.012)$ and $98.6 \%$ of beta diversity from unburned area $(\beta \mathrm{SOR}=$ 0.992: $\beta \mathrm{SIM}=0.978, \beta \mathrm{NES}=0.013)$.
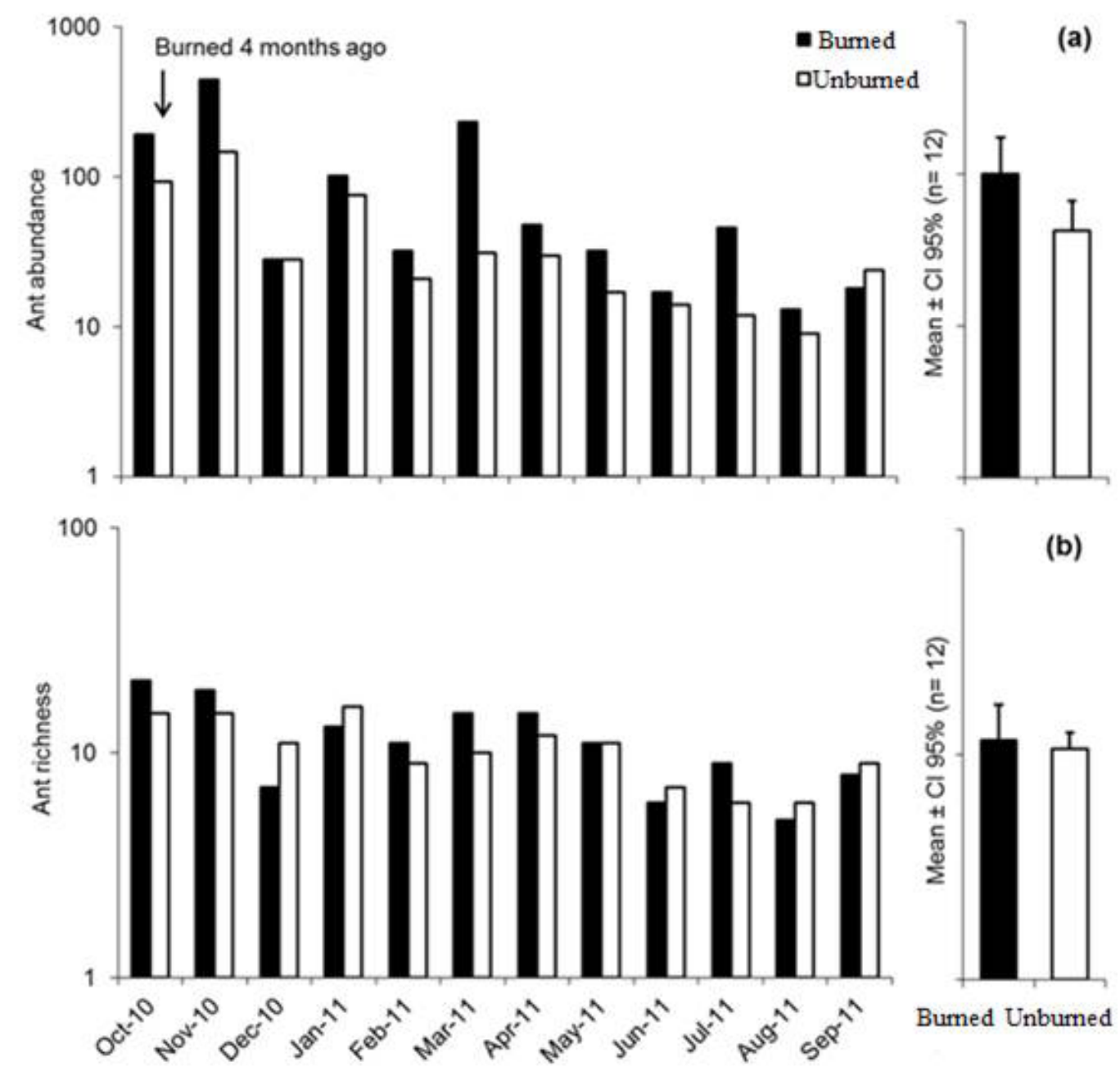

Fig 1. Total ant richness and abundance in studied areas along 12 months. Burned area was impacted four months before the beginning of the study, while the unburned area was not burned since the last decade. The two areas did not differ significantly with respect the richness (A), while the abundance is lower in the unburned area (B). 


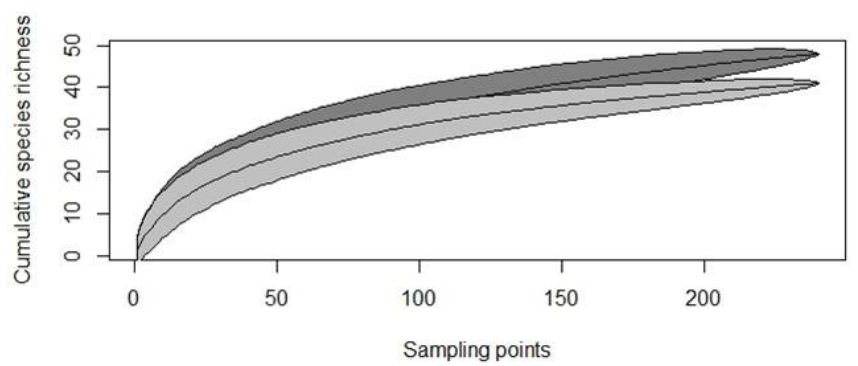

Fig 2. Curve of accumulated species richness per point over 12 months sampling, where the shaded area corresponds to the standard error. In dark gray the accumulated richness in burned area four months before the first sampling and in light gray accumulated richness in the unburned area.

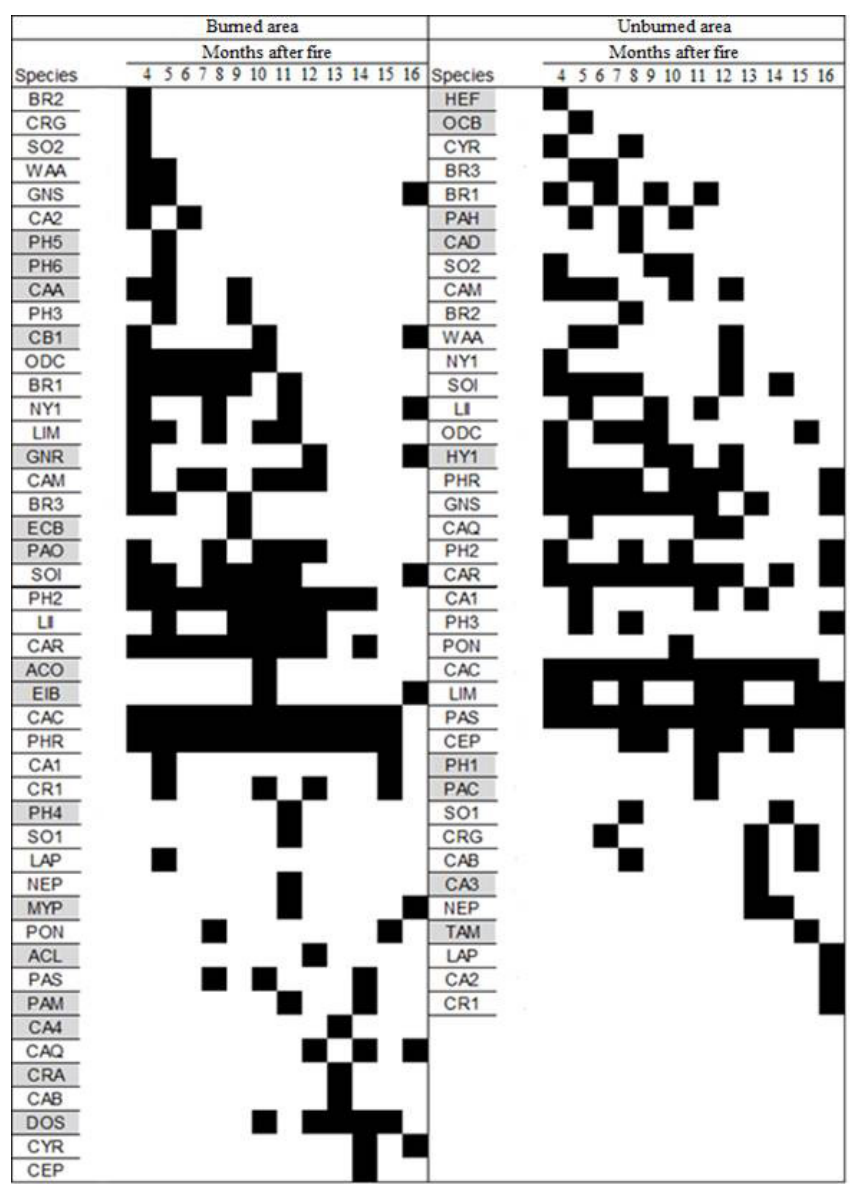

Fig 3. Temporal changes in the ant species fauna of both studied areas through the model 'Seriation'. A gradient of species replacement over time was observed in the burned area (right panel) and which did not occur in the unburned area (left panel). The species names are in abbreviations, which grey for exclusive species and white for represent common species.

\section{Discussion}

In this study, we refuted the hypothesis that fire changes the local ant mean species richness immediately after the burning, but we suggest that the effect acts in ant foraging rates, based on abundance data, such as found in Andersen et al. (2006). Although some studies have showed contrasting responses regarding the ant abundance (Andersen \& Yen, 1985; Andersen, 1991; Parr et al., 2004) we demonstrate that burned areas presented higher abundance than unburned area in the short term. Moreover, our results indicated that the ant assemblage's species composition changed over time after the fire as intensively as in the unburned area. However, in the former this had a trend into a new fauna instead of being a random variation in sampled ant species. Still, in both areas species changes were defined by substitution and not by nestedness patterns (i.e., loss of part of an expected fauna from global data). Although this mechanism explains the change within both studied areas, we emphasize that changes in the burned area differed from that expected just by chance while this change in the unburned area is random, as indicated by Seriation test.

There are two likely explanations to the maintenance of mean species richness after fire. First, the ant species richness was not affected by fire impacts. This statement sounds unlikely because the fire has direct effects on mortality of species that are foraging at the moment and indirect effects in habitat, indicating that any effect on ant community must exist (Gillon, 1983; Farji-Brener et al., 2002; Frizzo et al., 2011). Nevertheless, ants with nests underground may have higher tolerance to fire since soil protect the nest from burning, than other ground-nesting species (Miranda et al., 1993). Ants nesting below-ground would recover rapidly because they could re-enter the above-ground habitats after disturbance from their protected nests in the soil (Campos et al., 2007).

Secondly, in case of having severe fire effects, it is possible that the ant diversity had recovery four months after the fire passage only. Since the impressive ant resilience to fire (Parr et al., 2004, Barrow et al., 2007), we believe this short time was enough for the ant diversity recovery. For instance, there is data suggesting that diversity of ground ants in the rupestrian complex vegetation recovers faster than in the savanna (Parr et al., 2004; Vasconcelos et al., 2009). However, these effects depend on the intensity and frequency of disturbance, habitat susceptibility and community resilience (Farji-Brener et al., 2002; Ratchford et al., 2005; Barrow et al., 2007).

Regardless the absence of difference in ant mean species richness, the ant mean abundance was higher in the burned area than in the unburned area. Maravalhas \& Vasconcelos (2014) also did not found significant differences in the ant species richness between distinct regimes of fire. The lack of effects of fire on the ant assemblage species richness is contradictory to common sense, as many studies have shown null or positive effects of it (Parr et al., 2004; Andersen et al., 2006; Arnan et al. 2006) and as it is visually a severe impact. Nonetheless, an actual fire effect exists, but influences foraging and dominance. Both increasing ant abundance in the burned area. The ant abundance may increase after the fire for two possible and additive reasons: immediately after fire, the lack of vegetation layers increases the foraging activity on the ground, as usually seen in open environment (Andersen \& Yen, 1985; Whelan, 1995); secondly, after 
the fire impact, vegetation grew up and germinated quickly, increasing availability of resources (Alves-Silva \& Del-Claro, 2013; Fagundes et al., 2015). This result corroborates with Parr \& Andersen (2008) who also found that over the first four months after fire there was a considerable increase in the abundance of ants. Fagundes et al. (2015) found higher abundance of cavity-nesting ants, which usually foraged in the ground, in the burned than unburned area. Fire may affect the natural succession process creating opportunities for different species over time, whereas some species are favored and other are not (Andersen \& Muller, 2000). This succession dynamics was perceptible at any sampled month, due to the species turnover. Such high species/abundances changes along short periods of time are in support of our view that our sample design is not ecologically pseudo-replicated, as it detects a relevant ecological process.

Moreover, it is important to consider that sampling began in the rainy season when environmental conditions (high humidity, precipitation and temperature) also stimulate forage activity (Kaspari\& Weiser, 2000), and this effect may be more evident in burned area (Arnan et al., 2006). Beyond that, the ant's reproduction period also occur in the rainy season. The high colonization rate associated with low competition may be important to explain the observed species turnover being the principal mechanism related to beta diversity along time. In other hand, we unexpectedly found the same pattern in the unburned area, suggesting that species turnover may result from temporal partition of activity between species.

Anyway, after disturbance, the species richness may recover and different species composition may take place, depending on which species reinvade the litter patch, as occur in litter ant communities in forests (Campos et al., 2007), leading to a stronger species changes. In other hand, in the unburned area, we suggest that the ground ants are always changing because the litter is a very perishable environment and in theunburnedarea may have suffered natural and random disturbances (Campos et al., 2007). It is worth to notice that disturbance in litter communities occurs frequently because this microhabitat receives a constant input of vegetal and animal detritus, and also because this organic material is constantly subject to decomposition and incorporation into the soil (Facelli \& Pickett, 1991). In fact, litter ant assemblages in tropical forests may attain a high diversity due to a small-scale patch dynamics model, since these communities are naturally and constantly disturbed (Campos et al., 2007).

In summary, the recovery of rupestrian complex vegetation to fire disturbance occur by at least three distinct ways. First, the ant fauna can be highly resistant but weakly resilient, slightly changing after the fire but becoming extremely different over time. Secondly, the ant fauna may be little resistance and resilient, presenting great changes after the fire and slow long-term recovering (Andersen, 1991). Finally, as our results shown, the ant fauna can be very resistance and resilient to fire, showing little or no change after burning and rapid recovery (Parr et al., 2004; Vasconcelos et al., 2009). Recently, Fagundes et al. (2015) found high rates of new ant's colonies foundation in vegetation in this study site.

Changes in fire regime in rupestrian complex vegetation can lead to habitat modification, as observed for rainforests, creating opportunities for many species and compensates species loss (Cochrane et al., 1999; Silvério et al., 2013). Despite the fact that both areas have the same mechanism of ant composition changing along time, we found a considerable percentage of exclusive species $(30 \%)$ in the burned area than in the unburned one (14\%).

Our results showed that in the rupestrian complex vegetation ant fauna recover before the vegetation. Parr et al. (2004) and Andersen et al. (2014), suggest that little intense fire does not have effect on ground ant fauna, and our results indicate that the ant fauna in rupestrian complex vegetation are highly resistant and resilient to fire disturbance. Nevertheless, we observed species turnover over time, common in both areas but possibly due to different causes. In fact, we did conclude that the ant fauna in burned area presented composition changes higher than expected by chance and higher abundance, indicating increased activity of foraging, than in unburned area.

\section{Acknowledgments}

We are grateful to Dr. R Fagundes for suggestions which improved the quality of the manuscript; Dr. FS Neves and his helpful in statistics analysis; J. Aidan Manubay from GW University for his help with English language. We thank Instituto Chico Mendes (ICMBio) and Instituto Estadual de Florestas (IEF) for permission to research, Federal University of Ouro Preto and Laboratório de Ecologia Evolutiva de Insetos de Dossel e Sucessão Natural for logistic support. We also thank PROPP/UFOP, CAPES and CNPQ for financial support. SPR is a CNPq researcher granted.

\section{References}

Alves, R.J.V., Silva, N.G., Oliveira, J.A. \& Medeiros, D. (2014) Circumscribing campo rupestre- megadiverse Brazilian rocky montane savanas. Brazilian Journal of Biology, 2: 355-362. doi: 10.1590/1519-6984.23212.

Alves-Silva, E. \& Del-Claro, K. (2013). Effect of postfire resprouting on leaf fluctuating asymmetry, extrafloral nectar quality, and ant-plant-herbivore interactions. Naturwissenschaften, 100: 525-532. doi: 10.1007/s00114013-1048-z.

Andersen, A.N. (1988) Immediate and longer term effects of fire on seed predation by ants in sclerophyllous vegetation in southeastern Australia. Australian Journal of Ecology, 13: 285-293.

Andersen, A.N. (1991) Responses of ground-foraging ant communities to three experimental fire regimes in a savanna 
forest of tropical Australia. Biotropica, 23: 575-85.

Andersen, A.N, Hertog, T. \& Woinarski, J.C.Z. (2006) Long-term fire exclusion and ant community structure in an Australian tropical savanna: congruence with vegetation sucession. Journal of Biogeography, 33: 823-832. doi: 10.1111/j.13652699.2006.01463.x.

Andersen, A.N. \& Muller, W.J. (2000) Artropod responses to experimental fire regimes in an Australian tropical savannah: ordinal-level analysis. Austral Ecology, 25: 199-209. doi: 10.1046/j.1442-9993.2000.01038.x.

Andersen, A.N. \& Yen, A.L (1985) Immediate effects of fire on ants in the semi-arid mallee region of northwestern Victoria. Australian Journal of Ecology, 10: 25-30. doi: 10.1111/j.1442-9993.1985.tb00860.x.

Andersen, A.N., Ribbons, R.R., Pettit, M. \& Parr, C.L. (2014) Burning for diversity: highly resilience for ant communities respond only to strongly contrasting fire regimes in Australia's seasonal tropics. Journal of Applied Ecology, 51: 1406-1413. doi: 10.1111/1365-2664.12307

Arnan, X., Rodrigo, A. \&Retana, J. (2006) Post-fire recovery of Mediterranean ground ant community follows vegetation and dryness gradient. Journal of Biogeography, 33: 12461248. doi: 10.1111/j.1365-2699.2006.01506.x.

Baselga, A. (2010) Partitioning the turnover and nestedness components of beta diversity. Global Ecology and Biogeography, 19: 134- 143.

Baselga, A., Gómez-Rodríguez, C. \& Lobo, J.M. (2012) Historical Legacies in World AmphibianDiversity Revealed by the Turnover and Nestedness Components of Beta Diversity. Plos One, 7: 1-10. doi: 10.1371/journal.pone.0032341basel.

Barrow, L., Parr, C.L. \& Kohen, J.L. (2007) Habitat type influences fire resilience of ant assemblages in the semi-arid tropics of Norther Australia. Journal of Arid Environments, 69: 80-95.

Benites, V.M., Caiafa, A.N., Mendonça, E.S., Shaefer, C.E. \& Ker, J.C. (2003) Solos e vegetação nos comlexos rupestres de altitude da Mantiqueira e do Espinhaço. Floresta e Ambiente, 10: 76-85.

Brower, J.C. \&Kile, K.M. (1988) Sedation of an original data matrix as applied to paleoecology. Lethaia, 21: 79-93.

Campos, R.B.F., Schoereder, J.H. \&Speber, C.F. (2007) Small-scale patch dynamics after disturbance in litter ant communities. Basic and Applied Ecology, 8: 36-43. doi: 10.1016/j.baae.2006.03.010.

Costa, C.B., Ribeiro, S.P. \& Castro, P.T.A. (2010) Ants as Bioindicators of Natural Succession in Savanna an Riparian Vegetation Impacted by Dredging in the Jequitinhonha River Basin, Brazil. Restoration Ecology, 18, 148-157. doi: 10.1111/j.1526-100X.2009.00643.x.
Cochrane, M.A., Alencar, A., Schulze M.D., Souza, C.M., Nepstad, D.C., Lefebvre, P. \& Davidson, E.A. (1999) Positive feedbacks in the fire dynamic of closed canopy tropical forests. Science, 284: 1832-1835.

Conceição, A.A. \& Pirani, J.R. (2007) Diversidade em quatro áreas de campos rupestres na Chapada Diamantina, Bahia, Brasil: espécies distintas, mas riquezas similares. Rodriguésia, 58: 193-206.

Facelli, J.M. \& Pickett, S.T.A. (1991) Plant litter: Its dynamics and effects on plant community structure. The Botanical Review, 57: 1-32.

Fagundes, R., Anjos, D.V., Carvalho, R.L. \& Del-Claro, K. (2015). Availability of food and nesting-sites as regulatory mechanisms for the recovery of ant diversity after fire disturbance. Sociobiology, 62: 1-9 doi:10.13102/ sociobiology.v62il.1-9

Farji-Brener, A.G., Corley, J.C. \&Bettinelli, J. (2002) Effects of fire on ant communities in north-western Patagonia: the importance of habitat structure and regional context. Diversity and Distributions, 8: 235-243. doi: 10.1046/j.14724642.2002.00133.x.

Fernandes, G.W., Barbosa, N.P.U., Negreiros, D. \&Paglia, A.P. (2014) Challenges for the conservation of vanishing megadiverse rupestrian grasslands. Natureza e Conservação, 2: $162-165$.

Fernández, F. (2003) Lista de las espécies de hormigas de la región Neotropical. In: F. Fernández (Eds.), Introduccíon a las hormigas de la región Neotropical (pp 379-411). Bogotá: Instituto de Investigación de Recursos Biológicos Alexander von Humboldt Press.

Fowler, H.G., Delabie, J.H.C., Brandão, C.R.F., Forte,L.C. \& Vasconcelos, H.L. (1991) Ecologia nutricional de formigas. In: H.G. Fowler, J.H.C. Delabie, C.R.F. Brandão, L.C. Forte \& H.L. Vasconcelos (Eds.), Ecologia nutricional de insetos e suas implicações no manejo de pragas (pp: 131-209). Rio de Janeiro: Manole/CNPQ.

Frizzo,T.L.M., Bonizário, C., Borges, M.P. \& Vasconcelos, H.L. (2011) Revisão dos efeitos do fogo sobre a fauna de formações savânicas do Brasil. Oecologia Australis, 15: 365-379.

Gastauer, M., Messias, M.C.T.B. \& Neto, J.A.A.N. (2012). Floristic Composition, Species Richness and Diversity of Campo Rupestre Vegetation from Itacolomi State Park, Minas Gerais, Brazil. Environment and Natural Resources Research, 3:115-128. doi: 10.5539/enrr.v2n3p115.

Gillon, Y. (1983) The invertebrates of the grass layer. In: F. Boulièrie (Eds.), Ecosystems of the World 13: Tropical Savannas (pp: 289-311). Amsterdan, Holland: Elsevier.

Giulietti, A.M \& Pirani, J.R. (1988) Patterns of geographical distribution of some plants species from Espinhaçorange, Minas 
Gerais and Bahia, Brazil. In P.E.Vanzolini\& W.R. Heyer (Eds.), Proceedings of a workshop on Neotropical distribution patterns (pp: 39-69). Rio de Janeiro: Academia Brasileira de Ciências.

Harley, R.M. (1995) Introdução. In: Stannard B.L (Eds.), Flora of Pico das Almas, Chapada Diamantina - Bahia, Brazil. Kew, Royal Botanic Gardens.

Hoffmann, W.A., Orthen, B. \&Nascimento, P.K.V. (2003) Comparative fire ecology of tropical savanna and forest trees. Functional Ecology, 17: 720-726. doi: 10.1111/j.13652435.2003.00796.x.

Kauffmann, J.B, Cummings, D.L. \& Ward, D.E. (1994) Relationships of fire, biomass and nutrient dynamics along a vegetation gradient in Brazilian cerrado. Journal of Ecology, 82: 519-531.

Kaspari, M. \& Weiser, M.D. (2000) Ants activity along moisture gradients in a Neotropical forest. Biotropica, 32: 703-711.

Maravalhas, J. \&Vasconcelos, H.L. (2014) Revisiting the pyrodiversity-biodiversity hypothesis: long-term fire regimes and the structure of ant communities in the Neotropical savanna hotspot. Journal of Applied Ecology, doi: 10.1111/13652664.12338.

Miranda, A.C, Miranda, H.S., Dias, I.D.O. \& Dias, B.F.D. (1993) Soil and air temperatures during prescribed cerrado fires in Central Brazil. Journal of Tropical Ecology, 9: 313-320.

Miranda, H.S., Bustamante, M.M.C. \& Miranda, A.C. (2002). The Fire Factor. In: P.S. Oliveira \& R.J. Marquis (Eds.), Thecerrados of Brazil (pp. 51-68). New York: Columbia University Press.

Parr, C.L. \& Andersen, A.N. (2008) Fire resilience of ants assemblages in long-unburnt savanna of northern Australia. Austral Ecology, 33: 830-838. doi: 10.1111/j.14429993.2008.01848.x.

Parr, C.L., Robertson, H.G., Biggs, H.C. \& Chown, S.L. (2004) Response of African savanna ants to long-term fire regimes. Journal of Applied Ecology, 41: 630-642. doi: 10.1111/j.0021-8901.2004.00920.x.

Pedreira, G. \& Sousa, H.C. (2009) Composição florística e estrutura fitossociológica do componente arbóreo de uma mancha florestal permanentemente alagada e de sua vegetação adjacente no Parque Estadual do Itacolomi, Ouro Preto-MG, Brasil. Ciência Florestal, 21:665-677.

Ratchford, J.S., Wittman, S.E., Jules, E.S., Ellison, A.M., Gotelli, N.J. \& Sanders, N.J. (2005) The effects of fire, local environment and time on ant assemblages in fens and forest. Diversity and Distribution, 11: 487-497. doi: 10.1111/j.13669516.2005.00192.x.

Semir, J. (1991). Revisão taxonômica de Lychnophora Mart. (Vernoniaceae: Compositae). Tese de doutorado. Campinas, Universidade Estadual de Campinas.

Silvério, D.V., Brando, P.M., Balch, J.K., Putz, F.E., Nepstand, D.C., Oliveira-Santos, C. Bustamante, M.M.C. (2013) Testing the Amazon savannization hypothesis: fire effects on invasion of a neotropical forest by native cerrado and exotic pasture grasses. Philosophical Transactions of the Royal Society. B. 368: 2-8.

Simon, M.F., Grether, R., De Queiroz, L.P., Skema, C., Pennington, R.T. \& Hughes, C.E. (2009) Recent assembly of Cerrado, a Neotropical plant diversity hostpot, by in situ evolution of adaptations to fire. Proceedings of the National Academy of Sciences U.S.A, 106: 20359-20364. doi: 10.1073/ pnas.0903410106.

Vasconcelos, H.L., Leite, M.F.,Vilhena, J.M.S., Lima, A.P. \& Magnusson, W.E. (2008) Ant diversity in a Amazonia Savanna: Relationship with vegetation structure, disturbance by fire, and dominant ants. Austral Ecology, 33, 221-231. doi: 10.1111/j.1442-9993.2007.01811.x.

Vasconcelos, H.L., Pacheco, R., Silva, R.C., Vasconcelos, P.B., Lopes, C.T., Costa, N.A. \&Bruna, E.M. (2009) Dynamics of the Leafer Litter Arthropod Fauna Following fire in a Neotropical Woodland Savanna. Plos One 4: 1-9. doi: 10.1371/journal.pone.0007762.

Viana, P.L. \& Filgueiras, T.S. (2008) Inventário e distribuição geográfica das gramíneas (Poaceae) na Cadeia do Espinhaço, Brasil. Megadiversidade, 4: 99-116.

Whelan, R.J. (1995) The Ecology of Fire. United Kingdom: Cambridge University Press.

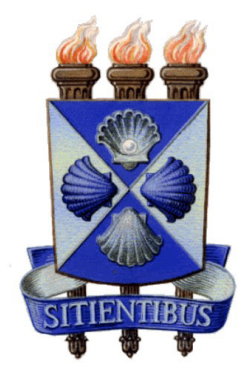

